\title{
Concomitance of numerical chromosomal alterations with structural in an elderly with Alzheimer's disease: a case report
}

\author{
Concomitância de alterações cromossômicas numéricas com estruturais em idoso \\ com doença de Alzheimer: relato de caso
}

\author{
Kledson Moraes Nunes (D)1, Talísia Nascimento Vianez (D)2, Denise Corrêa Benzaquem (D)1, \\ Natalia Dayane Moura Carvalho $\mathbb{D}^{1}$, Cleiton Fantin $\mathbb{D}^{1} \square$
}

1 Universidade do Estado do Amazonas, Laboratório de Citogenética, Escola Superior de Ciências da Saúde. Manaus, Amazonas, Brazil.

2 Universidade Federal do Amazonas, Departamento de Neurologia do Hospital Universitário Getúlio Vargas, Manaus, Amazonas, Brazil.

How to cite this article:

Nunes KM, Vianez TN, Benzaquem DC, Carvalho NDM, Fantin C. Concomitance of numerical chromosomal alterations with structural in an elderly with Alzheimer's disease: a case report. Sci Med. 2019;29(4):e34464. http://doi.org/10.15448/1980-6108.2019.4.34464

\section{ABSTRACT}

AIMS: To report the first case the concomitance of numerical chromosomal abnormalities with structural as well as chromosomal abnormalities structural in a patient diagnosed with Alzheimer disease in Manaus/Amazonas.

CASE DESCRIPTION: A male patient with 76 years of age was diagnosed with diagnosis of cognitive disorder- Alzheimer's disease with late onset - temporal variant after laboratory, physical and imaging exams. Cytogenetic analysis was requested for this patient, revealing the presence the concomitant of numerical and structural chromosomal abnormalities with metaphase cells composed of 45 chromosomes with the loss of one of the homologues of chromosome 21 (monosomy) and a deletion of the long arm of one of the homologues of chromosome 1 [45, XY, -21, del (1) (q?)] and metaphase cells containing 46 chromosomes with a deletion of the long arm of one of the homologues of chromosome 15 [(46, XY, del (15) (q?)]. Currently, the patient is in outpatient treatment for maintenance and control of the disease. CONCLUSIONS: Our study has underlined that karyotyping is one of the fundamental investigations for patients with Alzheimer's disease It highlighted, in the form of a chromosomal abnormality, may have been the risk factor in Alzheimer's disease.

KEYWORDS: Autosomal chromosomes, X chromosome, cytogenetics.

\section{RESUMO}

OBJETIVOS: Relatar o primeiro caso de concomitância de anormalidade cromossômica numérica com anormalidade cromossômica estruturais em um paciente diagnosticado com doença de Alzheimer em Manaus/Amazonas

DESCRIÇÃO DO CASO: Um paciente do sexo masculino com 76 anos de idade foi diagnosticado com distúrbio cognitivo - doença de Alzheimer com início tardio - variante temporal, após exames laboratoriais, físicos e de imagem. Análises citogenéticas foi solicitado para esse paciente, revelando a presença concomitante de anormalidades cromossômicas numéricas e estruturais com células metafásicas compostas por 45 cromossomos, com a perda de um dos homólogos do cromossomo 21 (monossomia) e a deleção do braço longo de um dos homólogos do cromossomo 1 [45, XY, -21, del (1) (q?)] e células metafásicas contendo 46 cromossomos apresentando deleção no braço longo de um dos homólogos do cromossomo 15 [(46, XY, del (15) (q?)] Atualmente, o paciente encontra-se em tratamento ambulatorial para manutenção e controle da doença.

CONCLUSÕES: Nosso estudo revelam que a cariotipagem é uma das investigações fundamentais para pacientes com doença de Alzheimer. A anormalidade cromossômicas pode ter sido o fator de risco para a doença de Alzheimer.

DESCRITORES: Cromossomos autossômicos, cromossomo X, citogenética. 
Abbreviation: AD, Alzheimer's disease.

\section{INTRODUCTION}

Alzheimer's disease (AD) is a degenerative brain disorder that compromises cognitive functions, affecting the individual's behavioral, social and professional performance [1]. The etiology is still unknown, however, there are several factors that have been investigated as a probable cause of $A D$, including cytogenetic, environmental, genetic, infectious and neuropathological factors [2-6]. Genetic studies have highlighted four genes responsible for $\mathrm{AD}$ as amyloid precursor protein, presenilin-1, presenilin-2 and Apolipoprotein E [6]. Chromosome analysis of peripheral blood lymphocytes cells, neuronal cells and buccal cells in $\mathrm{AD}$ patients shows a significant level of aneuploidy of the $\mathrm{X}$ chromosome and autossomic chromosomes as well as high percentage of premature centromere division compared to non-affected individuals [7-11]. To date, there is no information in the literature on the concomitance of numerical chromosomal abnormalities with structural in patients with Alzheimer's disease.

Thus, here we report the first case the concomitance of numerical (aneuploidy) chromosomal abnormalities with structural (deletion) as well as chromosomal abnormalities structural (deletion) in an elderly the 76 years of age with Alzheimer's disease in Manaus/ Amazonas.

\section{CASE DESCRIPTION}

Patient male, 76 years of age, married, incomplete elementary education, retired, cared for by family members and presenting forgetfulness for approximately six years. One of authors, due to short-term memory loss, attended patient. The patient underwent several consultations accompanied by his wife, in which he reported all the clinical symptoms of the patient.

His companion reported that patient had difficulties in activities of daily living, aggressiveness, agitation, auditory and visual hallucinations, ideational apraxia, eating difficulties and decreased appetite. No falls and sphincter dysfunction were reported. In the physical examination, it was observed that he was lucid and oriented in time and space, in good general condition, with a healthy complexion, hydrated, afebrile, eupneic, anicteric and without edema. In the neurological examination, the patient was alert and responsive and presented moderate bradykinesia and mild dysarthria. The Mini Mental State Examination revealed changes in orientation, attention and calculation, evocation and language (04/30 points). He used donepezil $10 \mathrm{mg}$ /day and quetiapine $25 \mathrm{mg} /$ day.

The companion reported improvements in the aggressiveness and hallucinations. However, he presented spatial disorientation at home with episodes of wandering from home, speech difficulties, weakness, difficulties in swallowing and chewing, difficulties in activities of daily living and restlessness during the day. In the physical examination, he presented a good general condition and was disoriented, anicteric, afebrile, acyanotic, with good complexion, hydrated and eupneic. In the neurological examination, preserved tonus, strength of muscle segments, and moderate bradykinesia. The Mini Mental State Examination revealed changes in orientation, attention and calculation, evocation and language (03/30 points).

A medical report was issued for the patient. The neurological report stated that "Patient is receiving regular monitoring in the Araújo Lima, Getúlio Vargas University Hospital, Outpatient Clinic with the diagnosis of cognitive disorder -Alzheimer's disease with late onset - temporal variant (Intenational Classification of Diseases' $-10^{\text {th }}$ Edition: G30.1). The patient presented anterograde amnesia, space-time disorientation and compromise of his activities of daily living, as well as apraxia of chewing and episodes of psychomotor agitation. The patient in question is dependent on his relatives around the clock and has no insight to respond to social questions by himself". Currently, the patient is in outpatient treatment for maintenance and control of the disease.

Cytogenetic analysis was requested for our patient. The resolution of 550 bands G-band karyotype obtained from the peripheral lymphocytes. In a total of 100 cells analyzed, two metaphasic cells showed chromosomal abnormalities. In a metaphasic cell showed the presence the concomitant of numerical and structural chromosomal abnormalities composed of 45 chromosomes with the loss of one of the homologues of chromosome 21 (monosomy) and a deletion of the long arm of one of the homologues of chromosome 1 [45, XY, -21, del (1) (q?)] (Figure 1a) and in a metaphasic cell containing 46 chromosomes with a deletion of the long arm of one of the homologues of chromosome 15 [(46, XY, del (15) (q?)] (Figure 1b). 


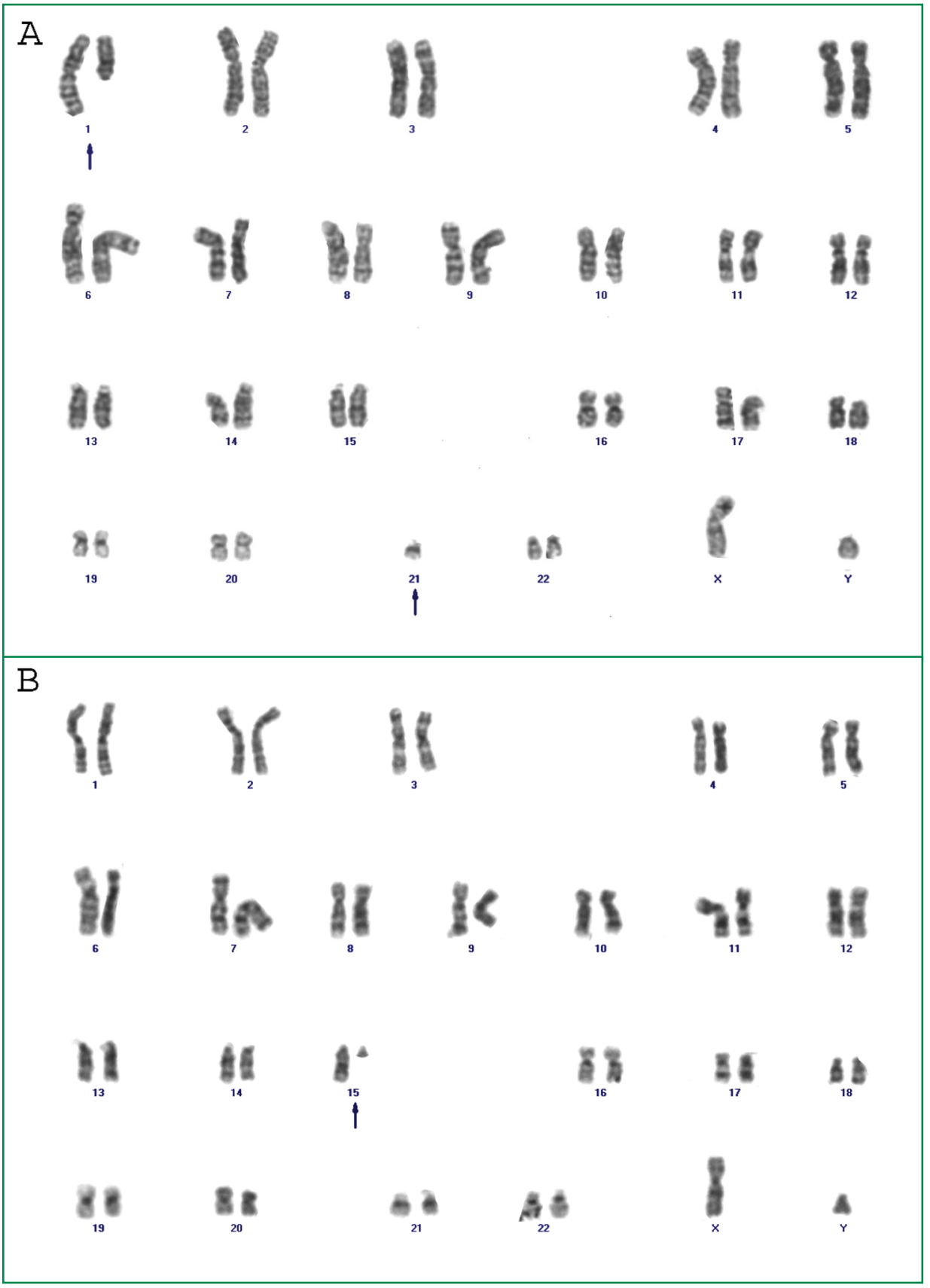

Figure 1. Karyotype of the patient diagnosed with Alzheimer disease. (A) Loss of one of the homologues of chromosome 21 and a deletion in the long arm of one of the homologues of chromosome 1. 45, XY,-21, $\operatorname{del}(1)(\mathrm{q}$ ?).

(B) Deletion in the long arm of one of the homologues of chromosome 15. 46, XY, del(15)(q?)

\section{DISCUSSION}

Alzheimer's disease is the most common form of dementia in older adults and is characterized by a progressive decline in cognitive and behavioral functions. In this case report, the patient was diagnosed with cognitive disorder due to Alzheimer's disease with late onset. This diagnosis was based on the clinical condition of the patient, results of the clinical examinations, physical examinations and neurological examinations. Thus, all the clinical information from patient corroborates the data related to this disease available in the literature [12].

Cytogenetic studies have contributed to the diagnosis of diseases related to chromosomal abnormalities and their relationship with dementia [13]. Several cytogenetic studies have reported the presence of numerical chromosomal abnormalities in patients with Alzheimer's disease, evidencing a high frequency of $\mathrm{X}$ chromosome aneuploidy and autossomic chromosomes [7-11]. Structural chromosomal abnormalities as well as concomitance of 
numerical chromosomal abnormalities with structural in patients with Alzheimer's disease not been reported in literature.

In our patient was observed the concomitant of the loss of one of the homologues of chromosome 21 (aneuploidy) and a deletion of the long arm of one of the homologues of chromosome 1 as also a deletion of the long arm of one of the homologues of chromosome 15, whose chromosome abnormalities are being revealed for the first time in the present work. The concomitant the numerical chromosomal abnormalities with structural is a rare abnormality and their presence, in humans, usually results in the apparition of multiple congenital abnormalities, problems on psychomotor development, cognitive deficits and neurological impairment $[14,15]$. So, the concomitance of the chromosomal abnormalities presents in the karyotype our patient may have resulted in serious consequences such as cognitive deficits, space-time disorientation as well as apraxia of chewing and episodes of psychomotor agitation.

In addition, numerical and structural chromosomal abnormalities may be associated with some genes directly linked to the pathogenesis of Alzheimer's disease, besides participating in a common neuropathogenic pathway [16]. That is, in our patient, the deletion of the long arm of one of the homologues of chromosomes 1 and 15 as well as loss of one of the homologues of chromosome 21 , entailed the loss of several genes such as the presenilin-2 gene localized on chromosome 1q42.13, the complement receptor type 1 gene localized on chromosome 1q32.2, the A disintegrin and metalloproteinase domain-containing protein 10 gene localized on chromosome $15 \mathrm{q} 21.3$ and, amyloid precursor protein gene localized on chromosome $21 \mathrm{q} 21.3$, respectively [17]. These genes have a function in transmembrane protein processing and intracellular signaling (presenilin-2); complement system activation, amyloid $\beta$ clearance; substrate of amyloid $\beta$ peptide and cell signaling events; cell cleavage and synthesis a-secretase in the brain $[17,18]$. Such genes are consistently associated with the establishment of AD. The loss of genes (or chromosome) that participate in neuropathogenic pathways, consequently, leads to serious problems in the function of these pathways, culminating in the development of several neurodegeneratic diseases [16].
Down syndrome patients usually manifest this neuropathology around the age of 40 years and have a greater expression of the amyloid precursor protein gene [19]. Thus, we suggest that the numerical and structural chromosomal abnormalities evidenced in the karyotype of our patient, might be contributing to the disease pathology of Alzheimer's disease.

However, several authors suggest the chromosomal abnormalities may not necessarily be related to Alzheimer's disease, but to aging, which is considered one of the risk factors for AD [2]. Yet, AD is a complex systematic disease that accelerates aging in which the chromosomes (autosomes and sexual chromosomes) may underlie instability of the AD cell genome leading to significant level of chromosomal abnormalities [20,21].

In conclusion, we report the first case of concomitant presence of numerical and structural chromosomal abnormalities in the patient with Alzheimer's disease. Our study has underlined that karyotyping is one of the fundamental investigations in the evaluation in the patient with Alzheimer's disease. It highlighted, in the form of a chromosomal abnormality, as the risk factors in Alzheimer's disease. More research is required to contribute to the knowledge the cytogenetics analyses of Alzheimer's disease.

\section{NOTES}

Part of this work is the result of a master's dissertation by one of the authors entitled "Evaluation of chromosomal changes in peripheral blood lymphocytes in patients with Alzheimer's disease.

\section{Funding}

This study did not receive financial support from external sources.

\section{Conflicts of interest disclosure}

The authors declare no competing interests relevant to the content of this study.

\section{Authors' contributions}

All the authors declare to have made substantial contributions to the conception, or design, or acquisition, or analysis, or interpretation of data; and drafting the work or revising it critically for important intellectual content; and to approve the version to be published.

\section{Availability of data and responsibility for the results}

All the authors declare to have had full access to the available data and they assume full responsibility for the integrity of these results. 


\section{REFERENCES}

1. Morley JE, Farr AS, Nguyen AD. Alzheimer Disease. Clin Geriatr Med. 2018;34(4):591-601. http://dx.doi. org/10.1016/j.cger.2018.06.006

2. Barranco-Quintana L, Allam F, Del Castillo S, Navajas F. Risk factors for Alzheimer's disease. Rev Neurol. 2005;40(10):613-18. http://dx.doi.org/10.3389/fnagi.2019.00146

3. Sochocka M, Zwolińska K, Leszek J. The infectious etiology of alzheimer's disease. Curr Neuropharmacol. 2017;15(7):996-1009. http://dx.doi.org/10.2174/1570159X15666170313122937

4. Ashraf GM, Tarasov VV, Makhmutova A, Chubarev VN, Avila-Rodriguez M, Bachurin SO, Aliev G. The possibility of an infectious etiology of alzheimer disease. Mol Neurobiol. 2019;56(6):4479-91. http://dx.doi.org/10.1007/s12035018-1388-y

5. Ahmad MH, Fatima M, Mondal AC. Influence of microglia and astrocyte activation in the neuroinflammatory pathogenesis of Alzheimer's disease: rational insights for the therapeutic approaches. J Clin Neurosc. 2018;59:6-11. http://dx.doi.org/10.1016/j.jocn.2018.10.034

6. Bettens K, Sleegers K, and Broeckhoven CV. Genetic insights in Alzheimer's disease. Lancet. 2013;12(1):92-104. http://dx.doi.org/10.1016/S1474-4422(12)70259-4

7. Ward BE, Cook RH, Robinson A, Austin JH. Increased aneuploidy in Alzheimer disease. Am J Med Genet A. 1979;3(2):137-44. http://dx.doi.org/10.1002/ajmg.1320030204

8. White BJ, Crandall C, Goudsmit J, Morrow CH, Alling DW, Gajdusek DC. Cytogenetic studies of familial and sporadic Alzheimer disease. Am J Med Genet A. 1981;10(1):77-89. http://dx.doi.org/10.1002/ajmg.1320100110

9. Buckton KE, Whalley LJ, Lee M, Christie JE. Chromosome changes in Alzheimer's presenile dementia. J Med Genet. 1983;20(1):46-51. http://dx.doi.org/10.1136/jmg.20.1.46

10. Iourov IY, Vorsanova SG, Liehr T, Yurov YB. Aneuploidy in the normal, Alzheimer's disease and ataxia-telangiectasia brain: differential expression and pathological meaning. Neurobiol Dis. 2009;34(2):212-20. http://dx.doi. org/10.1016/j.nbd.2009.01.003

11. Yurov YB, Vorsanova SG, Liehr T, Kolotii AD, Iourov IY. X chromosome aneuploidy in the Alzheimer's disease brain. Mol Cytogenet. 2014;7(1):7-20. http://dx.doi.org/10.1186/1755-8166-7-20

12. Truzzi A, Laks J. Doença de Alzheimer esporádica de início precoce. Rev Psiq Clin. 2005;32(1):43-6. http://dx.doi. org/10.1590/S0101-60832005000100006

13. Nordensson I, Beckman G, Adolfsson R, Bucht G, Winblad B. Cytogenetic changes in patients with senile dementia. Age Ageing. 1983;12(4):285-95. http://dx.doi.org/10.1093/ageing/12.4.285

14. Masarweh M. Chromosome 3q29 deletion with gastrointestinal malformation: a case report. J Med Case Rep. 2011;5(5):285-7. http://dx.doi.org/10.1186/1752-1947-5-285

15. Jhang KM, Chang TM, Chen M, Liu CS. Generalized epilepsy in a patient with mosaic Turner syndrome: a case report. J Med Case Rep. 2014;2(8):109-12. http://dx.doi.org/10.1186/1752-1947-8-109

16. Smith MAC. Doença de Alzheimer. Rev Bras Psiquiatr. 1999;21(2):1-5. http://dx.doi.org/10.1590/S151644461999000600003

17. Lambert JC, Ibrahim-Verbaas CA, Harold D, Naj AC, Sims R, Bellenguez C, De Stafano AL, Bis JC, Beecham GW. Meta-analysis of 74,046 individuals identifies 11 new susceptibility loci for Alzheimer's disease. Nat Genet. 2013;45(12):1452-58. http://dx.doi.org/10.1038/ng.2802

18. Karch CM, Ezerskiy LA, Bertelsen S; Alzheimer's Disease Genetics Consortium (ADGC) Goate AM. Alzheimer's disease risk polymorphisms regulate gene expression in the ZCWPW1 and the CELF1 loci. PLoS One. 2016;11(2):e0148717. http://dx.doi.org/10.1371/journal.pone.0148717

19. Geller LN, Potter H. Chromosome missegregation and trisomy 21 mosaicism in Alzheimer's disease. Neurobiol Dis. 1999;6(3):167-79. http://dx.doi.org/10.1006/nbdi.1999.0236

20. Bajic VP, Spremo-Potparevic B, Zivkovic L, Bonda DJ, Siedlak SL, Casadesus G, Lee HG, Smith MA. The $\mathrm{X}$-chromosome instability phenotype in Alzheimer's disease: A clinical sign of accelerating aging? Med Hypotheses. 2009;73(6):917-20. http://dx.doi.org/10.1016/j.mehy.2009.06.046

21. Bajic V, Mandusic V, Stefanova E, Bozovic A, Davidovic R, Zivkovic L, Cabarkapa A, Spremo-Potparevic B. Skewed X-chromosome inactivation in women affected by Alzheimer's disease. J Alzheimers Dis. 2015;43(4):1251-59. http://dx.doi.org/10.3233/JAD-141674 